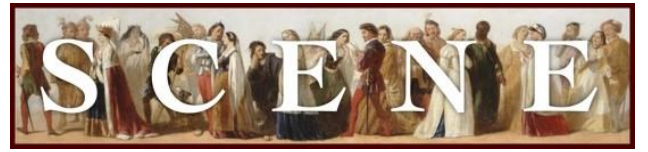

\title{
The Tempest at Shakespeare in the Park
}

\author{
by Matthew Zarnowiecki. Written on 2016-04-20. Published in 2017 Issue 1.
}

For the production: The Tempest (2015, New York Shakespeare Festival, USA). See production details at the end of the review.

THE TEMPEST URGES MANY QUESTIONS ON US. SOME OF THEM ARE HUMAN IN SCOPE: WHAT IS the price of wrongdoing? Who gets to wield power and why? Can repentance be enforced? Should it? Others are about artifice: What are the real effects of illusions? Are beautiful images inevitably false? Are artists' visions inevitably coercive? The Public Theater's production, directed by Michael Greif and starring Sam Waterston as Prospero, had definite answers to all of them. Some of the answers were better than others.

Audiences were able to track the answers through a few key moments of the play. There is "full fathom five," perhaps Shakespeare's most famous song. There is the wedding masque in Act 4, which Prospero puts on for Miranda and Ferdinand, whose romantic progress he had, until this point, been delaying. And there are the tricks of Ariel, especially a moment in Act 3 in which he first entices the starving and disoriented band of shipwrecked royals and courtiers with a seeming banquet, then after making it disappear, appears like a vengeful harpy and chastises them. These were the tests of stagecraft that the play put to its director, musicians, and actors.

On human terms, most of the play's key tests are at the end. Prospero addresses his brother venomously, and demands his dukedom; Antonio gets no lines at this point. Miranda has her moment of joyful admiration at the "brave new world" that has just been revealed to her, but in this same moment, Prospero-perhaps dismissively, or perhaps newly able to share Miranda's capacity for joy-says “Tis new to thee." And while Ariel gets to race away to airy freedom, there must be some final reckoning between Prospero and Caliban: an end to their strife, or a signal that it will have no end.

This production had elegant and satisfying answers to nearly every challenge of stagecraft. There were some technologically savvy bits of stage wizardry, including a gorgeous seascape of waves projected onto a scrim that ran across the entire stage (at least a hundred feet wide at the Delacorte). This changed color at times to match thin, square frames of light, bathing the stage in a mood-shifting combination of water and color, curves and angles. The "living drollery" of 
the banquet scene was taken quite literally here: a troupe of acrobatic ministrants swarmed Alonso and company, including one who could walk across the stage in a full back-bend, with a platter of fruit balanced on her upturned stomach. Another performed rope-dancing movements, which were also on exhibit during the storm scene. Ariel's harpy perches aloft at the center of the scaffold, with wings twenty feet wide each, made to flap jerkingly and menacingly by several stagehands. The masque scene was an elaborate, multi-song performance by Ceres, Juno, and company. It was both balletic and operatic, having renderedin full-the songs that many productions had cut.

In other words, this production provided big answers to the challenges of stagecraft, but they are not the over-polished, song-and-dance, Broadway in the park style we often see in summer Shakespeare. The stage design (Riccardo Hernandez), with its scaffolding and watery image projections, also included a bulky, irregular group of black painted rocks, which characters awkwardly stepped among. The costume design (Emily Rebholz) was striking and garish during the illusory banquet, when characters wore spiky helmets and spangling outfits, but otherwise it was staid. Caliban and Ariel each wore the same bondage-inspired network of leather straps across their torsos. While Ariel was often complemented with a breezy, open white oxford, and gray slacks (Prospero and others shared this simple outfit), Caliban was dirt-smeared from his jagged crew cut to his rumpled breeches.

The sounds and songs of the island composed by Michael Friedman—chiefly accomplished by Arthur Solari in his percussion booth, filled with timpani and a vibraphone, and also many sheets of metal, but with pre-recorded music as well-were all superb. The measure of the song, "full fathom five," was rendered beautifully by Chris Perfetti as Ariel. He did not sing it alone; instead, there were multi-part harmonies and echoes from members of the company, which washed over the spellbound Ferdinand (Rodney Richardson) as he remembered his father. Perfetti's Ariel and Louis Cancelmi's Caliban, although they were of air and earth, were the production's best answers to The Tempest's human questions. Perfetti's motions were lithe and delicate, his gazes piercing. Cancelmi cowered and writhed, and his tortured vulnerability was most evident when he was commanding his new master, Stephano, to kill Prospero. His insistence was ineffectual, and he blinked back raging tears, frustrated that he must serve such an idiot. An inspired and suitably wonder-struck performance was also given by Francesca Carpanini as Miranda.

Waterston, although, was not quite up to the task of Prospero's volatility. He blustered well, but far too much and too often, and without any corresponding quietness. Here, I think, Shakespeare in the Park itself was set against him. Waterston had to shout and gesticulate to make himself seen and known on the broad expanse of stage, against the waves and swaying 
trees. It was too much. He raged equally loudly when telling Miranda her origin story as when denouncing two different sets of conspirators (one from the past and one from the present) at the end of the play. His timing seemed often to throw the other actors off theirs, and his endless head-cocking distracted us from the range of Prospero's imperious punishments, fearful scheming, loving rebukes, and wistful remembrances.

It was almost as though this Prospero was transformed into a character who must endure Learlike spasms of tragic, cleaving anger. But in forty years of acting with The Public Theater, Waterston had already played Lear and many other Shakespearean parts, including his 1975 Hamlet, which might have accounted for this unusual reading of The Tempest's Prospero. That is why Greif's directorial choices at the end of the action were so jarring. He had Prospero mercilessly beat Caliban with his magic wand, every stroke amplified by an ear-splitting percussive jolt. Then, contrary to all indications of the text, Prospero was offered a double reconciliation rather than demanding penitence: he turned to face his brother Antonio, who must relinquish his crown, but Prospero suddenly and jauntily offered his hand, in a "put 'er there, old fellow" gesture, which Waterston rendered completely unironically. Even more significantly, his last, menacing commands to Caliban were softly spoken, and the master embraced his servant. It seemed as if Greif was calling for a long, tender, restorative moment. Instead, it struck an erring, false note. Caliban had been brilliantly rendered by Calcelmi as having, if not a speech impediment, at least some difficulty forming words in the language of his oppressor. He also went about with tortured, cramped arms and legs. His wracked body, I now realize, was not naturally this way; he had been beaten into this shape by Prospero. Caliban had endured the tyrant's cruelty throughout, and now, suddenly and inexplicably, he had to endure his love.

It is just possible that these moments were meant by Greif and Waterston to constitute an overwrought, impossibly happy ending. But I fear instead that they were meant in earnest. Either way, this production's adroit attention to theatrical illusion alleviated its ham-handed rendering of forgiveness. Just as Ariel was released from bondage, the entire scrim was made to fall away, fluttering down to the stage floor and revealing the production's skeleton, a bare metal scaffold. This was no fading of the insubstantial pageant, to "Leave not a rack behind." It was instead the hulking, unintended wreck of our disbelief, which no hug or handshake could dissolve.

Matthew Zarnowiecki is Chair of the Department of Languages and Literature at Touro College's Lander College for Women and Lander College for Men, New York. His research interests are in early modern literary studies, including Shakespeare, print and manuscript history, and lyric poetry. His monograph, Fair Copies: Reproducing the English Lyric from Tottel to Shakespeare (University of 
Toronto Press, 2014) examines the production and reproduction of poetry in printed collections. His articles have appeared in Critical Survey, Spenser Studies, The Sidney Journal, and EMLS, among other places.

\section{Production Details}

\section{General}

Title

Breath of Kings: Rebellion

Year 2016

Theater Company

Stratford Festival of Canada

Theaters

Tom Patterson Theatre (Canada)

Start Date

2016-06-22

End Date

2016-09-24

\section{Cast}

$\begin{array}{ll}\text { JUNO } & \text { WHITNEY BASHER } \\ \text { CALIBAN } & \text { LOUIS CANCELMI } \\ \text { MiRANDA } & \text { FRANCESCA CARPANINI } \\ \text { BOATSWAIN } & \text { NICHOLAS CHRISTOPHER } \\ \text { TRINCULO } & \text { JESSE TYLER FERGUSON } \\ \text { IRIS } & \text { OLGA KARMANSKY } \\ \text { CERES } & \text { TAMIKA LAWRENCE } \\ \text { STEPHANO } & \text { DANNY MASTROGIORGIO } \\ \text { ALONSO } & \text { CHARLES PARNELL } \\ \text { ARIEL } & \text { CHRIS PERFETTI } \\ \text { FERDINAND } & \text { RODNEY RICHARDSON } \\ \text { ANTONIO } & \text { COTTER SMITH } \\ \text { PROSPERO } & \text { SAM WATERSTON } \\ \text { GONZALO } & \text { BERNARD WhITE }\end{array}$

\section{Creatives}

$\begin{array}{ll}\text { Director } & \text { Michael Greif } \\ \text { Costume Designer } & \text { Emily Rebholz } \\ \text { Lighting Designer } & \text { David Lander } \\ \text { Sound Design } & \text { Jason Crysal } \\ \text { Sound Design } & \text { Acme Sound Partners } \\ \text { Music } & \text { Michael Friedman } \\ \text { Scene/Stage Designer } & \text { RicCardo Hernandez }\end{array}$




\section{Hair and MaKeup Design J. Jared Janas \\ SOUNDSCAPES MatT TiERNEY}

